\title{
Spirituality in childhood cancer care
}

\author{
This article was published in the following Dove Press journal: \\ Neuropsychiatric Disease and Treatment \\ 8 October 2013 \\ Number of times this article has been viewed
}

\author{
Nádia Nara Rolim Lima' \\ Vânia Barbosa do \\ Nascimento' \\ Sionara Melo Figueiredo \\ de Carvalho' \\ Modesto Leite Rolim Neto ${ }^{2}$ \\ Marcial Moreno Moreira ${ }^{2}$ \\ Aline Quental Brasil ${ }^{2}$ \\ Francisco Telésforo \\ Celestino Junior ${ }^{2}$ \\ Gislene Farias de Oliveira ${ }^{2}$ \\ Alberto Olavo Advíncula \\ Reis $^{3}$ \\ 'Health Sciences Postgraduate \\ Program, ABC Region Medical School, \\ Santo André, São Paulo, Brazil; \\ ${ }^{2}$ Department of Medicine, Federal \\ University of Ceará, Barbalha, Ceará, \\ Brazil; ' 3 Public Health Postgraduate \\ Program, University of São Paulo, São \\ Paulo, Brazil
}

Correspondence: Modesto Leite Rolim Neto

Faculty of Medicine, Federal University of Ceará, Rua Divino Salvador,

S/N, Rosário, Barbalha, Ceará, Brazil

Tel +55 88 969l I 385

Fax +55 883572720 I

Email modestorolim@yahoo.com.br
Abstract: To deal with the suffering caused by childhood cancer, patients and their families use different coping strategies, among which, spirituality appears a way of minimizing possible damage. In this context, the purpose of the present study was to analyze the influence of spirituality in childhood cancer care, involving biopsychosocial aspects of the child, the family, and the health care team facing the disease. To accomplish this purpose, a nonsystematic review of literature of articles on national and international electronic databases (Scientific Electronic Library Online [SciELO], PubMed, and Latin American and Caribbean Health Sciences Literature [LILACS]) was conducted using the search terms "spirituality," "child psychology," "child," and "cancer," as well as on other available resources. After the search, 20 articles met the eligibility criteria and were included in the final sample. Our review showed that the relation between spirituality and health has lately become a subject of growing interest among researchers, as a positive influence of spirituality in the people's welfare was noted. Studies that were retrieved using the mentioned search strategy in electronic databases, independently assessed by the authors according to the systematic review, showed that spirituality emerges as a driving force that helps pediatric patients and their families in coping with cancer. Health care workers have been increasingly attentive to this dimension of care. However, it is necessary to improve their knowledge regarding the subject. The search highlighted that spirituality is considered a source of comfort and hope, contributing to a better acceptance of his/her chronic condition by the child with cancer, as well as by the family. Further up-to-date studies facing the subject are, thus, needed. It is also necessary to better train health care practitioners, so as to provide humanized care to the child with cancer.

Keywords: spirituality, child, child psychology, neoplasms, cancer

\section{Introduction}

Childhood cancer has an enormous impact on the lives of children and their families, forcing them to face stressful experiences, full of anguish, fear and suffering. ${ }^{1,2}$ Generally, cancer involves a prolonged treatment that demands care and implies several changes, such as adaptations to new routines, new discourses, new situational settings regarding uncertainties about the treatment course, anxiety and fear of dying, changes in affective and emotional contexts, and concerns about financial welfare and family cohesion, bringing feelings of doubt and impotence. ${ }^{3}$ This context can lead the child and the relatives to depressive states, discouragement, hopelessness, confusion, and exaustion. $^{2}$

Receiving a cancer diagnosis is an intense personal experience, based on universal, cultural, and familiar meanings. To deal with the suffering caused by cancer, patients 
and their relatives use different coping strategies, and patients frequently use spirituality to cope with the disease. ${ }^{1,4,5}$

Spirituality is described in a broader sense than religion, being related to issues such as the meaning and purpose of life, and using spiritualistic beliefs to seek these answers. ${ }^{6}$ In 1988, the World Health Organization (WHO) deepened investigations regarding spirituality, which was included in the WHO multidimensional definition of health. Nowadays, spiritual welfare is still considered a health dimension, among physical, psychic, and social dimensions. ${ }^{7}$

Especially regarding cancer patients, spirituality seems to involve the search of the meaning and purpose of life, improving the quality of life of the child and his/her family. Scientific studies are being carried out to investigate possible influences of spirituality in human health. Spirituality has also been considered a dimension that must be included in a global care to the patient. ${ }^{8}$

The purpose of this study was to analyze the influence of spirituality in childhood cancer care, involving biopsychosocial aspects of the child, the family, and the health care team facing the disease.

\section{Methods}

The present study is a nonsystematic review of literature. At first, a search of the literature was conducted via national and international electronic databases (Scientific Electronic Library Online [SciELO], PubMed, and Latin American and Caribbean Health Sciences Literature [LILACS]) using different combinations of Medical Subject Headings (MeSH) terms "spirituality," "child psychology," "child," and "cancer," and equivalents in Portuguese. Additional references were also gathered from the reference lists of the retrieved articles.

The title and abstracts of the retrieved articles were entirely read, and a matrix including title of journal/article, year of publication, subject, and type of publication was done. The search strategy and the retrieved articles were reviewed separately by the authors to ensure adequate sampling.

The article analysis followed previously determined eligibility criteria. Inclusion criteria were as follows: (A) articles about spirituality in childhood cancer care; (B) manuscripts written in English or Portuguese; (C) recent manuscripts regarding the subject; (D) original articles with online accessible full text available in Coordination of Improvement of Higher Education Personnel (CAPES) Journal Portal, a virtual library linked to Brazil's Ministry of Education and subjected to content subscription; ${ }^{9}$ (E) prospective or retrospective observational (analytical or descriptive, except case reports), experimental or quasi-experimental studies, and reviews of literature. Exclusion criteria were: (A) other designs, such as case reports and series of cases; and (B) nonoriginal studies, including editorials, brief communication, and letters to the editor.

\section{Results}

After carrying out the search strategies and analyzing title and abstract according to the eligibility criteria, 20 articles were retrieved and included in the final sample. From this total, ten $(50.0 \%)$ manuscripts ${ }^{1,10-18}$ were found in PubMed database, four $(20.0 \%)^{5,19-21}$ retrieved in SciELO database, one $(5.0 \%)^{4}$ was found in LILACS database, and five $(25.0 \%)^{2,7,8,22,23}$ manuscripts were found in the reference lists of the retrieved articles.

Table 1 provides an overview of all studies included in the final sample and of all data elements used during the data analysis process. Study designs included only nonexperimental studies. The 20 studies were distributed in the previously determined two categories as follows: importance of spirituality to patients, their families and caregivers; and strengthening of spirituality in the health care context.

\section{Discussion}

The relation between spirituality and health has lately become a subject of growing interest among researchers, as a positive influence of spirituality in the people's welfare was noted. The studies retrieved in the present review adopt a global view of health, dealing with subjects in their different dimensions and overcoming the biomedical model, which only highlights the physical aspect of the health-disease process and acts as a mechanistic idea of the body and its functions, being responsible for a fragmented treatment. ${ }^{22}$

An observational study by Batista et $\mathrm{al}^{4}$ show that the patient's quality of life regarding peace aspects is higher the more the patient's level of spirituality. This evidences that, more than only focusing on the disease, it is also important to consider the patient's subjective aspects, to transmit inner peace. $^{4}$

\section{Importance of spirituality to patients, their families, and their caregivers}

Consciously or unconsciously, children may somehow participate in a spiritual life. They express their spirituality by a variety of behaviors, such as rite simulation and games involving creativity. Studies show that children who develop their spirituality and have spiritual care have more 
Table I Spirituality in childhood cancer care: studies and main findings

\begin{tabular}{|c|c|c|c|}
\hline Authors & Journal & Category & Main findings \\
\hline Batista et $\mathrm{al}^{4}$ & Revista Bioética & $\begin{array}{l}\text { Importance of spirituality } \\
\text { to patients, their families, } \\
\text { and their caregivers }\end{array}$ & $\begin{array}{l}\text { The study showed that the higher level of spirituality, the greater quality } \\
\text { of life regarding peace. This conclusion leads to the reflection that it is } \\
\text { important to focus not only on the disease, but also on the subjective } \\
\text { aspects that provide inner peace. }\end{array}$ \\
\hline Foster et $\mathrm{al}^{10}$ & $\begin{array}{l}\text { Seminars in } \\
\text { Oncology Nursing }\end{array}$ & $\begin{array}{l}\text { Strengthening of spirituality } \\
\text { in the health care context }\end{array}$ & $\begin{array}{l}\text { Spiritual care includes the creation of environments in which children } \\
\text { and their families can continue to grow, especially throughout the illness } \\
\text { experience. Attending to a person's spirit respects the inherent inseparable } \\
\text { relationship of mind-body-spirit and honors and responds to the core being } \\
\text { of each person, recognizing his or her uniqueness. }\end{array}$ \\
\hline Kamper et al" & $\begin{array}{l}\text { Journal for } \\
\text { Specialists in } \\
\text { Pediatric Nursing }\end{array}$ & $\begin{array}{l}\text { Importance of spirituality } \\
\text { to patients, their families, } \\
\text { and their caregivers }\end{array}$ & $\begin{array}{l}\text { Children's care will be enhanced when given the opportunity to express } \\
\text { their spiritual and relational concerns. Children's responses were primarily } \\
\text { relational in nature, particularly to their parents. Seventy-eight percent of the } \\
\text { interviewees reported they did something to "feel close to God." Children } \\
\text { prayed for a "sense of normalcy" (59\%) and relational concerns (31\%). }\end{array}$ \\
\hline Faria et al' & $\begin{array}{l}\text { Estudos de } \\
\text { Psicologia (Natal) }\end{array}$ & $\begin{array}{l}\text { Importance of spirituality } \\
\text { to patients, their families, } \\
\text { and their caregivers }\end{array}$ & $\begin{array}{l}\text { The study confirms, through a qualitative approach, that the possibility of } \\
\text { giving a meaning to the disease (eg, God's will), diminishes feelings of guilt of } \\
\text { the caregiver. Beliefs and spirituality give meaning to life, mitigating conflicts } \\
\text { created by suffering and unexpected situations. }\end{array}$ \\
\hline Angelo et $\mathrm{a}^{2}$ & $\begin{array}{l}\text { O Mundo da } \\
\text { Saúde }\end{array}$ & $\begin{array}{l}\text { Importance of spirituality } \\
\text { to patients, their families, } \\
\text { and their caregivers }\end{array}$ & $\begin{array}{l}\text { Results of the study evidenced that suffering from cancer diagnosis of a child } \\
\text { stimulates in the family a new way of looking at life, and that spirituality can } \\
\text { have different meanings to the family while dealing with the disease. }\end{array}$ \\
\hline Fornazari et $\mathrm{al}^{5}$ & $\begin{array}{l}\text { Psicologia: Teoria } \\
\text { e Pesquisa }\end{array}$ & $\begin{array}{l}\text { Importance of spirituality } \\
\text { to patients, their families, } \\
\text { and their caregivers }\end{array}$ & $\begin{array}{l}\text { All participants referred to having a belief before receiving the diagnosis. } \\
\text { However, this belief was deepened, and they hold to it more frequently after } \\
\text { diagnosis. }\end{array}$ \\
\hline Pedrão et $\mathrm{a}^{8}$ & Einstein & $\begin{array}{l}\text { Strengthening of spirituality } \\
\text { in the health care context }\end{array}$ & $\begin{array}{l}\text { The assessment of spiritual welfare of nurses showed that the majority of the } \\
\text { nurses presented positive scores. It was considered important to offer the } \\
\text { patient spiritual assistance. However, the majority of the interviewed nurses } \\
\text { reported not having received a professional training on spiritual assistance in } \\
\text { their graduation courses. }\end{array}$ \\
\hline Alves et $\mathrm{a}^{22}$ & $\begin{array}{l}\text { O Mundo da } \\
\text { Saúde }\end{array}$ & $\begin{array}{l}\text { Strengthening of spirituality } \\
\text { in the health care context }\end{array}$ & $\begin{array}{l}\text { Spirituality/religiosity of patients is not fully comprehended. This can be due } \\
\text { to lack of training or sensibility of health care professional. The study shows } \\
\text { that it is important to overcome the biomedic model and the fragmented } \\
\text { view of the patient, so as he/she can be treated as a whole. }\end{array}$ \\
\hline Mueller et al ${ }^{15}$ & Pediatric Nursing & $\begin{array}{l}\text { Strengthening of spirituality } \\
\text { in the health care context }\end{array}$ & $\begin{array}{l}\text { Children are born with "spiritual competence," an inner quality or power for } \\
\text { faith development. Increased demands on time and rapidly changing complex } \\
\text { medical cases allow less time and energy directed toward spiritual issues for } \\
\text { the nurse, while at the same time increasing the possibility of spiritual needs } \\
\text { of the child and family. }\end{array}$ \\
\hline $\begin{array}{l}\text { Nascimento } \\
\text { et } \mathrm{a}^{20}\end{array}$ & $\begin{array}{l}\text { Acta Paulista de } \\
\text { Enfermagem }\end{array}$ & $\begin{array}{l}\text { Strengthening of spirituality } \\
\text { in the health care context }\end{array}$ & $\begin{array}{l}\text { Religion and spirituality are sources of comfort and hope and have helped } \\
\text { children and adolescents to better accept their chronic condition. }\end{array}$ \\
\hline Angelo et $\mathrm{al}^{23}$ & $\begin{array}{l}\text { Escola Anna } \\
\text { Nery Revista de } \\
\text { Enfermagem }\end{array}$ & $\begin{array}{l}\text { Importance of spirituality } \\
\text { to patients, their families, } \\
\text { and their caregivers }\end{array}$ & $\begin{array}{l}\text { The mother needs to find support in faith, in "something" that transcends } \\
\text { her strength and people's support. It is important for the mother to have } \\
\text { a place where she could feel comforted in the moments of fragility and } \\
\text { practice her spirituality. }\end{array}$ \\
\hline Hinds et $\mathrm{al}^{12}$ & $\begin{array}{l}\text { Journal of Clinical } \\
\text { Oncology }\end{array}$ & $\begin{array}{l}\text { Importance of spirituality } \\
\text { to patients, their families, } \\
\text { and their caregivers }\end{array}$ & $\begin{array}{l}\text { Among parents whose child died in a pediatric intensive care unit, } 73 \% \\
\text { identified faith-based sources of comfort at the end of their child's life. Four } \\
\text { religious themes were identified: prayer, faith, access to clergy, and belief } \\
\text { that the parent-child relationship endures beyond death. Faith is important } \\
\text { to some parents at this point in their child's care. Clinicians can support } \\
\text { parents' faith-related practices by asking about parents' beliefs, religious } \\
\text { symbols, or practices and asking how clinicians can best show their respect. }\end{array}$ \\
\hline $\begin{array}{l}\text { Schneider and } \\
\text { Mannell }{ }^{13}\end{array}$ & $\begin{array}{l}\text { Issues in } \\
\text { Comprehensive } \\
\text { Pediatric Nursing }\end{array}$ & $\begin{array}{l}\text { Importance of spirituality } \\
\text { to patients, their families, } \\
\text { and their caregivers }\end{array}$ & $\begin{array}{l}\text { Data show that spirituality and faith, no matter how they are defined, appear } \\
\text { to be important factors in the childhood cancer journey. Most parents in this } \\
\text { study described their spirituality as being an effective coping mechanism. Not } \\
\text { all parents defined spirituality from a purely religious perspective, though. } \\
\text { During these difficult times, parents questioned their beliefs but did not turn } \\
\text { away from their faith. }\end{array}$ \\
\hline
\end{tabular}


Table I (Continued)

\begin{tabular}{|c|c|c|c|}
\hline Authors & Journal & Category & Main findings \\
\hline $\begin{array}{l}\text { Moreira-Almeida } \\
\text { et al }{ }^{19}\end{array}$ & $\begin{array}{l}\text { Revista Brasileira } \\
\text { de Psiquiatria }\end{array}$ & $\begin{array}{l}\text { Importance of spirituality } \\
\text { to patients, their families, } \\
\text { and their caregivers }\end{array}$ & $\begin{array}{l}\text { There is enough evidence that religious involvement is frequently associated } \\
\text { with a better mental health state. }\end{array}$ \\
\hline Ross $^{16}$ & $\begin{array}{l}\text { Journal of Clinical } \\
\text { Nursing }\end{array}$ & $\begin{array}{l}\text { Importance of spirituality } \\
\text { to patients, their families, } \\
\text { and their caregivers }\end{array}$ & $\begin{array}{l}\text { Clients and their families should benefit from care which is more holistic } \\
\text { and addresses their deepest concerns and needs. }\end{array}$ \\
\hline Paro et $\mathrm{al}^{18}$ & $\begin{array}{l}\text { Arquivos de } \\
\text { Ciências da Saúde }\end{array}$ & $\begin{array}{l}\text { Strengthening of spirituality } \\
\text { in the health care context }\end{array}$ & $\begin{array}{l}\text { The study identified that the caregiver is a complex being with feelings, } \\
\text { needs, difficulties, and perceptions regarding his/her surroundings, but with a } \\
\text { limited ability to cope with and change stressing situations, such as death in } \\
\text { childhood. }\end{array}$ \\
\hline Kane et al ${ }^{14}$ & $\begin{array}{l}\text { Journal of Pediatric } \\
\text { Oncology Nursing }\end{array}$ & $\begin{array}{l}\text { Strengthening of spirituality } \\
\text { in the health care context }\end{array}$ & $\begin{array}{l}\text { The concept of stress-buffering may also be relevant in spiritual support. } \\
\text { Many agree that the keys to emotional coping with serious illness and } \\
\text { disability are frequently found within the matrix of spirituality. Improved } \\
\text { understanding of the social and spiritual support process will allow us to } \\
\text { implement interventions designed to minimize the suffering and improve } \\
\text { the quality of life of children living with and dying from serious illnesses and } \\
\text { their families. }\end{array}$ \\
\hline Lemos et $\mathrm{al}^{21}$ & $\begin{array}{l}\text { Revista Latino- } \\
\text { Americana de } \\
\text { Enfermagem }\end{array}$ & $\begin{array}{l}\text { Strengthening of spirituality } \\
\text { in the health care context }\end{array}$ & $\begin{array}{l}\text { The study involved patients subjected to intrathecal chemotherapy and } \\
\text { showed that patients find in spirituality, whether through beliefs or prayers, a } \\
\text { coping strategy to face the challenges presented by the disease. }\end{array}$ \\
\hline Taylor ${ }^{17}$ & Cancer Nursing & $\begin{array}{l}\text { Strengthening of spirituality } \\
\text { in the health care context }\end{array}$ & $\begin{array}{l}\text { The study identified spiritual needs associated with an "ultimate other;" the } \\
\text { need for positivity, hope, and gratitude; the need to give and to receive love; } \\
\text { the need to review beliefs, the need to have meaning; and needs related to } \\
\text { religiosity and preparation for death. }\end{array}$ \\
\hline $\mathrm{WHO}^{7}$ & $\begin{array}{l}\text { Social Science } \\
\text { and Medicine }\end{array}$ & $\begin{array}{l}\text { Strengthening of spirituality } \\
\text { in the health care context }\end{array}$ & $\begin{array}{l}\text { The WHOQOL includes a spiritual dimension (the person's perception } \\
\text { of "meaning in life" or the overarching personal beliefs that structure and } \\
\text { qualify experience). We have argued elsewhere that the broad physical, } \\
\text { psychological, social, and spiritual domains of quality of life are universal } \\
\text { values across cultures, and there is some evidence that this is so. Based on } \\
\text { the focus group data, several revisions were made to the proposed structure } \\
\text { of the instrument. For example, religion and spirituality were consistently } \\
\text { suggested as important dimensions of quality of life. }\end{array}$ \\
\hline
\end{tabular}

Abbreviations: WHO, World Health Organization; WHOQOL, World Health Organization Quality of Life.

positive coping strategies, sharing resilience as a protection factor. ${ }^{15}$

The practice of spirituality in childhood cancer care involves not only the patient, but also the family of the pediatric patient. Schneider and Mannell, ${ }^{13}$ in a study conducted among parents of children with cancer, demonstrated that there is a need for orientation by a spiritual counselor, highlighting the importance of spirituality to the family, in a situation of disease. The majority of the parents find it difficult to deal with their faith when the child's health state worsens; faith was also cited as a source of comfort and as an extremely personal issue. During difficult times, some parents questioned their beliefs, but they did not have their faith shaken. In this sense, the health care professional can give support to the spiritual practices of the parents, volunteering to pray with them, if they feel at ease doing so. ${ }^{13}$

In cancer, suffering often becomes a part of the routine of the children and their families. The experience of childhood cancer suffering has been described, highlighting the narratives of uncertainty related to the treatment process. The impact of uncertainty to the family reflects in the moments of confusion, despair, worries, exhaustion, discouragement, that are peculiar to the suffering regarding the battle against cancer. $^{2}$

Another study, one that focused on the mothers' needs while facing the difficulties of having a child with cancer, points out that it is important for the mother to have a place where she could feel comforted in the moments of fragility. Being able to cry far from the eyes of her son/daughter is a need and assures the mother of her own fragility and limitation, also giving her the conscience that she has to be strong so as to support her child. ${ }^{23}$

Faria and Cardoso $^{1}$ highlight spirituality as a coping strategy for caregivers of children with leukemia. The study assessed the level of stress of 20 caregivers, and pointed to spirituality, along with "problem solving" and "escape and 
avoidance," as a relief to the suffering resulting from a cancer diagnosis, where caregivers seek strength to deal with the situation and continue their caregiving function.

In this context, most studies show that spirituality can act as a way of adaptation to stress in a health context. ${ }^{19}$ Spirituality was found to be a source of comfort and hope and has helped to better accept the chronic condition by the child. ${ }^{20}$ There is enough evidence that spirituality rises as a striving factor of hope for children with cancer and their families, at the same time protecting them against despair and helping them to cope with difficulties. ${ }^{2}$

\section{Strengthening of spirituality in the health care context}

Recent studies show that the health care team has become more sensitive to this specific dimension of care. However, additional studies are still necessary to identify and to evaluate the adequate practices, to clarify concepts, and to contribute to professional improvement. ${ }^{16}$ The participation of the health care practitioner is hampered by a curriculum that does not adequately prepare him to deal with subjective dimensions that are not expressed in a rational and clear way. That is why it is crucial for health care professionals to acknowledge their own spiritual language, assumptions, and experiences, ${ }^{17}$ so as to provide a broader care to children with cancer.

It is of note that the spirituality herein studied does not relate to a specific religious belief; instead, it refers to the relation between the subject and the divine and the consequences of this relationship, such as attitudes, thoughts, feelings, and their manifestations in each individual. It is a dimension that is beyond the limits of the universe and that is related to the search for a meaning for life..$^{5,12}$

Facing the importance of enabling health care professionals to adequately approach spirituality, the strategies in Table 2 bring important findings on how the health care team must deal with the patients' and the caregivers' spirituality in the health context. These strategies show that the health care team's work must overcome the strict objective of treating the disease, successfully creating an environment in which the pediatric cancer patient recognizes what happens to him/her, only then being able to understand the meaning of his/her disease and finding solutions to cope with this new life context. ${ }^{21}$

Having this in mind, and also considering that children are spiritual beings whose expression of spirituality may be limited by the capacity of the adults to understand them, childhood cancer care might contemplate the child's particular world and stages in a holistic way, regarding the
Table 2 Practical strategies for the health care team to develop/ reinforce the spirituality of the pediatric patient and his/her family

I. Support the ill child's and family's established coping strategies. ${ }^{10}$

2. Affirm hope through kindness and a purposeful, active presence. ${ }^{10}$

3. Try to create an atmosphere conducive to social and spiritual interactions that can evolve, over time, into relationships with supportive meaning. ${ }^{14}$

4. Assess children's spiritual needs. When the assessment process itself is done with sensitivity, interest, and receptiveness, a line of communication between the health care practitioner and the child and his or her family opens. ${ }^{15}$

5. School-aged children may be more self-directed in their spiritual practices. Nurses should ask if they use prayer, plan times for spiritual expression, and provide quiet time when appropriate. ${ }^{15}$

6. Children should be allowed opportunities for expression of spirituality through art, music, or stories. ${ }^{15}$

7. Establish with the pediatric patient a relationship that allows you to talk to him/her about what is meaningful to them."

individual and his/her family, in an attempt to satisfy the child's needs. $^{18}$

\section{Conclusion}

Cancer, in itself, defies the child and his/her family. In this context, people ask themselves about faith and religiosity, and spiritual care may or may not be desired, depending on the way the families of children with cancer understand or recognize the meaning of their lives through spirituality. This review was able to verify that spirituality is considered a source of comfort and hope and has helped in the better acceptance of the chronic condition of the children with cancer and their families.

However, to achieve a better understanding regarding the subject, further studies are needed, exploring the impact of spirituality in the experience of pediatric cancer. Health care practitioners must also be better qualified, so as to identify the right moment to interfere and offer families of pediatric patients and patients themselves strategies that deal with spiritual care, providing the child with a fuller and more humanized care.

\section{Disclosure}

The author reports no conflicts of interest in this work.

\section{References}

1. Faria AMDB, Cardoso CL. Aspectos psicossociais de acompanhantes cuidadores de crianças com câncer: stress e enfrentamento. [Psychosocial aspects of caregivers of children with cancer: stress and coping]. Estud psicol. 2010;27:13-20. Portuguese.

2. Angelo M. Ouvindo a voz da família: narrativas sobre sofrimento e espiritualidade. [Hearing the voice of the family: narratives about suffering and spirituality]. Mundo Saúde (Online). 2010;34:437-443. Portuguese. 
3. Zanelato AP, Angelo M. A família vivenciando a situação de ter um filho com câncer. [The family's experience towards a child with cancer]. Rev Bras Ciencias Saúde. 2003;1(2):44-48. Portuguese.

4. Batista S, Mendonça ARA. Espiritualidade e qualidade de vida nos pacientes oncológicos em tratamento quimioterápico. [Spirituality and quality of life in oncologic patients undergoing chemotherapy treatment]. Rev bioét. 2012;20(1): 175-188. Portuguese.

5. Fornazari SA, Ferreira RER. Religiosidade/espiritualidade em pacientes oncológicos: qualidade de vida e saúde. [Religiousness/spirituality in oncological patientes: life quality and health]. Psic: Teor e Pesq. 2010;26: 265-272. Portuguese.

6. Powell LH, Shahabi L, Thoresen CE. Religion and spirituality. Linkages to physical health. Am Psychol. 2003;58(1):36-52.

7. World Health Organization. The World Health Organization Quality of Life assessment (WHOQOL): position paper from the World Health Organization. Soc Sci Med. 1995;41(10):1403-1409.

8. Pedrão RB, Beresin R. O enfermeiro frente à questão da espiritualidade. [Nursing and spirituality]. Einstein. 2010;8:86-91. Portuguese.

9. Coordination of Improvement of Higher Education Personnel (CAPES) Journal Portal [homepage on the Internet]. Brasília: Coordination of Improvement of Higher Education Personnel (CAPES); 2013. Available from: http://www.periodicos.capes.gov.br/. Accessed September 13, 2013.

10. Foster TL, Lafond DA, Reggio C, Hinds PS. Pediatric palliative care in childhood cancer nursing: from diagnosis to cure or end of life. Semin Oncol Nurs. 2010;26(4):205-221.

11. Kamper R, Van Cleve L, Savedra M. Children with advanced cancer: responses to a spiritual quality of life interview. J Spec Pediatr Nurs. 2010;15(4):301-306.

12. Hinds PS, Oakes LL, Hicks J, et al. "Trying to be a good parent" as defined by interviews with parents who made phase I, terminal care, and resuscitation decisions for their children. J Clin Oncol. 2009;27(35): 5979-5985.
13. Schneider MA, Mannell RC. Beacon in the storm: an exploration of the spirituality and faith of parents whose children have cancer. Issues Compr Pediatr Nurs. 2006;29(1):3-24.

14. Kane JR, Hellsten MB, Coldsmith A. Human suffering: the need for relationship-based research in pediatric end-of-life care. J Pediatr Oncol Nurs. 2004;21(3):180-185.

15. Mueller CR. Spirituality in children: understanding and developing interventions. Pediatr Nurs. 2010;36(4):197-203.

16. Ross L. Spiritual care in nursing: an overview of the research to date. J Clin Nurs. 2006;15(7):852-862.

17. Taylor EJ. Spiritual needs of patients with cancer and family caregivers. Cancer Nurs. 2003;26(4):260-266.

18. Paro D, Paro J, Ferreira DLM. [O enfermeiro e o cuidar em Oncologia Pediátrica]. Arq Ciênc Saúde. 2005;12(3):151-157. Portuguese.

19. Moreira-Almeida A, Lotufo Neto F, Koenig HG. Religiousness and mental health: a review. Rev Bras Psiquiatr. 2006;28(3):242-250.

20. Nascimento LC, Oliveira FCS, Moreno MF, et al. Cuidado espiritual: componente essencial da prática da enfermeira pediátrica na oncologia. [Spiritual care: an essential component of the nurse practice in pediatric oncology]. Acta Paul Enferm. 2010; 23(3):437-440. Portuguese.

21. Lemos FA, Lima RA, Mello DF. Caring for children and adolescents with cancer: the intrathecal chemotherapy phase. Rev Lat Am Enfermagem. 2004;12(3):485-493. Portuguese [with English abstract].

22. Alves JS, Junges JR, López LC. A dimensão religiosa dos usuários na prática do atendimento à saúde: percepção dos profissionais da saúde. [The religious dimension of users in the practice of health assistance: perception of health professionals]. Mundo Saúde (Online). 2010;34(4):430-436. Portuguese.

23. Angelo M, Moreira PL, Rodrigues LMA. Uncertainties in the childhood cancer: understanding the mother's needs. Esc. Anna Nery. 2010;14(2):301-308.
Neuropsychiatric Disease and Treatment

\section{Publish your work in this journal}

Neuropsychiatric Disease and Treatment is an international, peerreviewed journal of clinical therapeutics and pharmacology focusing on concise rapid reporting of clinical or pre-clinical studies on a range of neuropsychiatric and neurological disorders. This journal is indexed on PubMed Central, the 'PsycINFO' database and CAS.

\section{Dovepress}

The manuscript management system is completely online and includes a very quick and fair peer-review system, which is all easy to use. Visit http://www.dovepress.com/testimonials.php to read real quotes from published authors. 